\title{
CARLTONA - A MATTER OF INTENTION
}

\section{Introduction}

The Supreme Court's decision in $R v$ Adams $^{1}$ clarifies some of the factors by which courts may identify the intention of Parliament with regard to the Carltona principle; that is, to identify whether Parliament intends that a power conferred on, say, a Secretary of State may be exercised by a subordinate, a junior Minister or a Civil Servant. The Court also considered whether they may invoke rule in Pepper $v \mathrm{Hart}^{2}$ and thereby consult parliamentary material.

The case was an appeal by Gerry Adams, the former President of Sinn Féin, against two convictions in 1975 for attempting to escape lawful custody. Mr Adams had attempted to escape his detention under the policy of internment whereby those suspected of involvement in terrorism could be detained without trial. The central question for the Court was whether the interim custody order (ICO) under which he was detained was valid.

The ICO had been made under the Detention of Terrorists (Northern Ireland) Order 1972. Article 4(1) of the Order empowers the Secretary of State to make an ICO for those he or she suspects of being engaged in terrorism. The Court assumed, and all parties accepted, that the decision to detain Mr Adams had been made by a junior Minister rather than the Secretary of State. ${ }^{3}$ The question was whether, following Carltona, this was permissible under the 1972 Order - in which case Mr Adams' detention would have been lawful and his convictions for attempting to escape that detention would stand - or whether the matter had

\footnotetext{
${ }^{1}$ [2020] UKSC 19, [2020] 1 WLR 2077.

2 [1993] AC $593(\mathrm{HL})$.

${ }^{3}$ Adams (n 1) [4].
} 
to be personally considered by the Secretary of State, in which case Mr Adams' appeal would succeed.

The Supreme Court, reversing the decision of the Northern Ireland Court of Appeal, ${ }^{4}$ held that article 4(1) required the personal consideration of the Secretary of State. Thus, Mr Adams' detention under the ICO had been invalid and his convictions for attempting to escape that detention should be quashed.

\title{
The Carltona principle
}

The issue in Carltona $v$ Commissioners of Works $^{5}$ was whether an order requisitioning the plaintiff’s factory under the Defence (General) Regulations 1939 was lawfully made given that it was taken by an Assistant Secretary in the Ministry of Works and Planning rather than a Commissioner (ie: a Minister) personally. The Court of Appeal found that the requisitioning order was valid. Lord Greene MR said:

\begin{abstract}
In the administration of government in this country the functions which are given to ministers (and constitutionally properly given to ministers because they are constitutionally responsible) are functions so multifarious that no minister could ever personally attend to them. To take the example of the present case no doubt there have been thousands of requisitions in this country by individual ministers. It cannot be supposed that this regulation meant that, in each case, the minister in person should direct his mind to the matter. The duties imposed upon ministers and the powers given to ministers are normally exercised under the authority of the ministers by responsible officials of the department. Public business could not be carried on if that were not the case. Constitutionally, the decision of such an official is, of course, the decision of the minister. The minister is responsible. It is he who must answer before Parliament for
\end{abstract}

\footnotetext{
${ }^{4} R v$ Adams (Gerard) [2018] NICA 8. For a critical account of this decision see Karl Laird 'R. $v$ Adams - the Carltona principle and internment in Northern Ireland' [2019] Crim LR 771. ${ }^{5}$ [1943] 2 All ER 560 (CA).
} 
anything that his officials have done under his authority, and, if for an important matter he selected an official of such junior standing that he could not be expected competently to perform the work, the minister would have to answer for that in Parliament. ${ }^{6}$

This, then, is the Carltona principle: that functions bestowed on Ministers may be lawfully exercised by Departmental officials, simply because it would not be possible, and so could not have been intended, for Ministers to exercise all such functions personally. Where such a function is exercised by an official, the Minister is responsible, and may have to answer, to Parliament ${ }^{7}$ if, say, he or she permits the power to be exercised by someone whose lack of seniority or experience means that they cannot be expected to undertake the function competently. ${ }^{8}$

Yet, as the Supreme Court's decision in Adams demonstrates, the principle does not always apply. The decision-maker named in the legislation - often the Secretary of State may be expected to exercise the power personally. Lord Kerr, giving the unanimous

\footnotetext{
${ }^{6}$ ibid 563.

${ }^{7}$ This idea that the Minister remains responsible to Parliament for power exercised by a subordinate on his or her behalf is fundamental; as such, the principle will not apply if there is a break in the chain of accountability, for instance, where the person exercising the power is statutorily independent, see Mark Elliott and Jason NE Varuhas, Administrative Law: Text and Materials ( $5^{\text {th }}$ edn, OUP 2016) $168-170$.

${ }^{8}$ Pitchford LJ states that the official acting on the Minister's behalf must be someone "properly qualified to make the judgment", Castle v DPP [2014] EWHC, [2014] 1 WLR 4279 [28]. It should also be noted that the courts, as well as Parliament, may also provide oversight of any devolvement of a Minister's powers by judicial review or, say, if the matter is raised in criminal proceedings, Adams (n 4) [15] (Sir Ronald Weatherup).
} 
judgment of the court, elucidated some of the considerations which courts should take into account when deciding when this is the case.

\section{Identifying Parliament's intention}

It is apparent throughout Lord Kerr's judgment that, when determining whether the Carltona principle applies to a particular exercise of power, the intention of Parliament is the determining consideration: the courts should identify whether Parliament's intention is that the function should be exercised by the named decision-maker personally or by a subordinate on their behalf. ${ }^{9}$ The courts will have regard to various factors when ascertaining this intention. In Adams, Lord Kerr considers the language used in the 1972 Order, the seriousness of the power to detain people and whether personally making an ICO would place an excessive burden on the Secretary of State. His Lordship also considered whether there is a presumption in favour of the Carltona principle. I consider these matters below.

The language used in the legislation is the starting point in identifying Parliament's intention. Parliament may explicitly state that the power conferred must be exercised personally thereby excluding the Carltona principle in terms. For example, section 30(1)(a) of the Investigatory Powers Act 2016 states: "The decision to issue a warrant under this Chapter must be taken personally by the Secretary of State ..."

\footnotetext{
${ }^{9}$ As I say, this is evident throughout the judgment and particularly in the penultimate paragraph where Lord Kerr states: "For these reasons [ie: because of the factors he considers throughout the judgment], I have concluded that it was Parliament's intention that the power under article 4(1) of the 1972 Order should be exercised by the Secretary of State personally", Adams (n 1) [40] (emphasis added).

${ }^{10}$ emphasis added.
} 
Alternatively, Parliament's intention that the Carltona principle should apply in one instance may be inferred from it being excluded in other provisions within the legislation. That is, if some provisions of a statute specify that a function must be exercised personally by the Secretary of State, those that do not may be construed as permitting the Carltona principle to apply. Lord Kerr uses the example of the Immigration Act 1971 which was considered in Oladehinde. ${ }^{11}$ He notes there are three instances in the Act which confer power on the Secretary of State and which are "accompanied by words such as 'not [to be exercised] by a person acting under his authority"'. The absence of such words with regard to a notice of intention to deport, which was at issue in the case, meant that the Carltona principle was not excluded; the notice could be issued by officials acting under the Secretary of State's authority:

Not only was there no express limitation [on the Secretary of State's ability to authorise officials to issue a notice of intention to deport] but the presence of express exclusion of delegation in other sections was a clear indication that the implication of such an exclusion [of the Carltona principle] in relation to the issue of an intention to deport was inapt. $^{12}$

Lord Kerr undertook a similar analysis of the difference between the relevant provisions of the Detention of Terrorists (Northern Ireland) Order 1972; indeed, it was the primary factor in the Supreme Court's conclusion that Parliament intended that the order to detain the appellant should be made personally by the Secretary of State rather than an official acting under his or her authority. The Court examined articles 4(1) and 4(2) of the Order:

\footnotetext{
${ }^{11} R v$ Secretary of State for the Home Office, ex p Oladehinde [1991] 1 AC 254 (HL).

${ }^{12}$ Adams (n 1) [16] (Lord Kerr)
} 
Article 4(1)

Where it appears to the Secretary of State that a person is suspected of having been concerned in the commission or attempted commission of any act of terrorism or in the direction, organisation or training of persons for the purpose of terrorism the Secretary of State may make an order (hereafter in this Order referred to as an 'interim custody order') for the temporary detention of that person.

Article 4(2)

An interim custody order of the Secretary of State shall be signed by a Secretary of State, Minister of State or Under Secretary of State.

Lord Kerr notes that that there is a division of labour here: article 4(1) refers to the making of an ICO whereas 4(2) refers to the signing of an ICO. This suggests the two roles the making of an ICO and its signing - should be undertaken separately and differently. This, in turn, indicates that it was intended that the Carltona principle should not apply to making an order:

If it had been intended that the Carltona principle should apply, there is no obvious reason that these roles should be given discrete treatment. It would have been a simple matter to provide in [article 4(1)] that the Secretary of State 'may make [and sign]' an ICO. The question therefore arises, why was provision made for the different roles in two separate paragraphs of the article. The answer appears to me to be self-evident: it was intended that the two functions called for quite distinct treatment. ${ }^{13}$

Lord Kerr also notes that article 4(2) states that it is an "interim custody order of the Secretary of State" 14 that should be signed indicating that the ICO should be made by the Secretary of State personally:

\footnotetext{
${ }^{13}$ ibid [31].

14 emphasis added.
} 
The use of the words, 'of the Secretary of State' surely denotes that the ICO is one which is personal to him or her, not a generic order which could be made by any one of the persons named in [article 4(2), ie: a Secretary of State, Minister of State or Under Secretary of State]. ${ }^{15}$

A further consideration in determining the intention of Parliament is whether the personal undertaking of the function by the named decision-maker would be excessively burdensome. Indeed, this is the primary reason for the principle given by Lord Greene in the Carltona case: “... the functions which are given to ministers are functions so multifarious that no minister could ever personally attend to them". ${ }^{16}$ On the other hand, if the evidence suggests that the personal exercise of the power in question would not be too onerous, this indicates that Parliament intended the Carltona principle should not apply.

In Adams, Lord Kerr states that there was no evidence that, at the time the order to detain Mr Adams was made, it could not be considered personally by the then Secretary of State, William Whitelaw. He also notes that Mr Whitelaw's successor, Merlyn Rees, considered all ICOs personally, further indicating that the burden was not excessive:

... the fact that Mr Rees was able to carry out this task himself from March 1974 onwards is a clear indication that it should not have been impossibly difficult for $\mathrm{Mr}$ Whitelaw to do the same in July 1973, some eight months earlier. ${ }^{17}$

\footnotetext{
${ }^{15}$ Adams (n 1) [32].

${ }^{16}$ Text to $\mathrm{n} 6$.

${ }^{17}$ Adams (n 1) [19].
} 
The courts might also consider the seriousness of the decision-making power when deciding whether it must be exercised personally or not. ${ }^{18}$ Once again, though, this is a consideration only to the extent that it makes "a contribution to the insight that it would provide as to Parliament's intention, rather than ranking as an autonomous factor". ${ }^{19}$ And it is not necessarily the most significant consideration in identifying that intention. ${ }^{20}$ In Adams, the gravity of the decision - depriving liberty - taken alongside the analysis of the relevant provisions provided such insight: "that the intention [of Parliament] was that such a crucial decision should be made by the Secretary of State". ${ }^{21}$

Though it was not necessary for the present case, Lord Kerr also considered whether there is a presumption in favour of the Carltona principle applying to exercises of Ministerial power. He refrained from answering this question but obviously thought it might be putting the matter too strongly to claim that there is such a presumption. Rather, he preferred an open-ended examination of the [relevant] factors ... namely, the framework of the legislation, the language of pertinent provisions in the legislation and the 'importance of

\footnotetext{
18 ibid [14].

${ }^{19}$ ibid [21].

${ }^{20}$ ibid [14]. It is worth bearing in mind the following passage from De Smith's Judicial Review: "It may be that there are, however, some matters of such importance that the minister is legally required to address himself to them personally ... It is ... possible that orders drastically affecting the liberty of the person - e.g. deportation orders, detention orders made under wartime security regulations and perhaps discretionary orders for the rendition of fugitive offenders require the personal attention of the minister", Harry Woolf and others, De Smith 's Judicial Review ( $2^{\text {nd }}$ sup, $8^{\text {th }}$ edn, Sweet $\&$ Maxwell 2018) 5-187. See, also, Laird (above n 4) 780 and 783. However, if this is correct, I suggest that this is only because the courts are assuming that Parliament must intend that such important matters may only be taken by the named Minister. ${ }^{21}$ Adams (n 1) [38].
} 
the subject matter', in other words, the gravity of the consequences flowing from the exercise of the power.. $.2^{22}$

This open-ended examination should be undertaken while keeping in mind Lord Griffiths' comment in Oladehinde that a "statutory duty placed on a minister may 'generally' be exercised by a member of his department" ${ }^{23}$ and that Parliament legislates "against the background that the Carltona principle is well-established". ${ }^{24}$

\section{Pepper v Hart}

One question considered by both the Northern Ireland Court of Appeal and the Supreme Court is whether the rule in Pepper $v$ Hart $^{25}$ could be invoked. This permits reference to parliamentary material to help determine the meaning of legislation if three conditions are met: that the words used in the legislation were obscure, ambiguous or where their literal meaning would lead to an absurdity; that the material relied on were statements by a Minister or other promoter of the Bill, along with any material necessary to understand these statements; and, that the statements relied on were clear. ${ }^{26}$

${ }^{22}$ ibid [26].

${ }^{23}$ Lord Kerr, ibid [16], [25]-[26] referring to Lord Griffith's speech in $R v$ Secretary of State for the Home Office, ex p Oladehinde [1991] 1 AC 254 (HL) 303. This echoes Brightman J's statement that "as a general rule" Ministerial power may be exercised by appropriate officials, Re Golden Chemical Products Ltd [1976] Ch 300 (Ch) 306. It is also reminiscent of Lord Greene's statement in Carltona: "The duties imposed upon ministers and the powers given to ministers are normally exercised under the authority of the ministers by responsible officials of the department", above n 6 (emphasis added).

${ }^{24}$ Adams (n 1) [25].

${ }^{25}$ Above $\mathrm{n} 2$.

${ }^{26}$ ibid 640 (Lord Browne-Wilkinson). 
Both courts held that the language of the 1972 Order was clear (that is, that the first of the above conditions was not met) and, consequently, there could be no reference to parliamentary material. This was so even though - as Lord Kerr notes, seemingly with some appreciation of the irony - the two courts came to different conclusions about whether the legislation permitted the Carltona principle to apply when making an ICO. ${ }^{27}$

\section{Conclusion}

When determining whether the Carltona principle applies to a particular exercise of power, the courts should attempt to identify the intention of Parliament. In doing this, they should consider various factors including: the provisions which confer the power and any other provisions providing evidence of Parliament's intention; the burden placed on the Minister if he or she were to personally exercise the power; and the gravity of any consequences flowing from the exercise of power.

Lord Kerr's caution against presuming that the Carltona principle applies may also indicate the importance of identifying Parliament's intention. His preference for an "openended examination" of the relevant factors - while remaining cognisant that a Ministerial function may generally be exercised by a subordinate and that Parliament legislates "against the background that the Carltona principle is well-established" - may be more likely to identify Parliament's intention. The alternative, adopting as a starting point a presumption in favour of the principle that has to be rebutted by contrary evidence, may obscure, and lead to a decision which runs contrary to, that intention.

${ }^{27}$ Adams (n 1) [33]-[36]. The Northern Ireland Court of Appeal also held that the statements on which the appellant attempted to rely were contradictory, Adams (n 4) [22]. 
The Carltona principle is an essential feature of modern government in the UK; as Lord Greene states, the administration of the country could not be undertaken without it, Ministers could not personally exercise all the powers conferred on them. ${ }^{28}$ This is even more the case now given the expansion in the complexity and range of government since the Carltona decision in the 1940s. Yet, it is also essential to ensure that its operation is consistent with Parliament's intention so that the imperative of administrative efficiency does not override constitutional propriety.

\footnotetext{
${ }^{28}$ Above n 6.
} 